\title{
THE PRINCIPLE OF QUALITY OF LIFE VERSUS SANCTITY OF LIFE IN THE EUTHANASIA DEBATE: WHERE DOES ISLAMIC LAW STANDS?
}

\author{
Omipidan Bashiru Adeniyi*
}

\begin{abstract}
The trend in most part of the western world today is the agitations for a person to have the right to take his own life, when such life, becomes unbearable due to pain, being the result of a severe or terminal illness. This is the position of proponents of the concept of euthanasia and assisted suicide. Opponents of the concept on the other hand are of the view that no matter the circumstances, a person should not take his own life because he has contributed nothing to its creation. They therefore uphold the sanctity of life as against its quality. This paper seeks to examine the relative arguments and will address the position of Islamic law governing the euthanasia debate.
\end{abstract}

Keywords: quality of life, sanctity of life, euthanasia, position of Islamic law

* $\quad$ L.L.B, (Unilorin), L.L.M (Ife), Ph.D (IIUM), B.L, Lecturer, Faculty of Law, University of Ilorin, Nigeria. 


\begin{abstract}
ABSTRAK
Trend di kebanyakan tempat di dunia Barat hari ini adalah desakan agar seseorang mempunyai hak untuk mengambil nyawanya sendiri, apabila jiwa tersebut, menjadi tidak tertahan disebabkan kesakitan, akibat penyakit yang teruk atau yang boleh membawa maut. Inilah pendirian penyokong konsep eutanasia dan bunuh diri ketolongan. Penentang konsep tersebut, di pihak yang lain, berpandangan bahawa walau apa pun keadaan, seseorang tidak sepatutnya mengambil nyawanya sendiri kerana dia telah tidak menyumbangkan apaapa dalam penciptaannya. Oleh yang demikian mereka mendukung kekudusan nyawa berbanding kualiti kehidupan. Makalah ini meneliti alasan kedua-dua pihak dan akan memberi perhatian kepada pendirian undang-undang Islam dalam perdebatan tentang eutanasia.
\end{abstract}

Kata kunci: kualiti kehidupan, kekudusan nyawa, eutanasia, pendirian undang-undang Islam

\title{
INTRODUCTION
}

The euthanasia debate, all over the world, particularly in the west, is centred on the quality of life. ${ }^{1}$ Generally speaking, the term, 'quality of

$1 \quad$ Euthanasia is derived from the Greek word eu (Good) and Thanathos (Death). Hence, it can be defined, as a painless free death. In other words, it is a means whereby a person ends his life, or is assisted to do so, because of terminal illness and or unbearable sufferings. The concept is legal in Oregon, Washington and Montana, in the United States of America, the Netherlands, Belgium, Switzerland, Luxembourg, and there are guidelines indicating situations when same is permitted in the United Kingdom. It is however important to note here that in the United States of America and Britain, it is called assisted suicide, while Switzerland allows both physician and non physician assisted suicide. 
life,' as noted in this article, has multifarious meanings. It depends on the context in which it is used. Thus, in the context of the advocates of euthanasia and assisted suicide, which is the focus of this write-up, the term has been employed to drive home support for the right to die. According to advocates of this concept, a person should be allowed to kill himself, when he feels that his quality of life is poor. ${ }^{2}$ In other words,

Assisted suicide is a process whereby a doctor writes a prescription of a lethal drug for a person, with the aim of using same to commit suicide, in order for him, according to advocates of the concept, to be able to die with dignity, as a result of poor quality of life. But in the Netherlands, Belgium and Luxembourg, euthanasia and assisted suicide are legal. Euthanasia would also include the case of a person whose quality of life is poor, in his own estimation, or that of his doctor, is injected to die with dignity, rather than continue to live in pain. The summary of the provisions of the laws of the above countries, and jurisdictions on euthanasia and assisted suicide is to the effect that on the basis of poor quality of life, a person should, rather than wallow in pain, either kill himself, or be assisted to do that. See http:// www.euthanasia.com> (Accessed 10 March, 2010) Wikipedia, The Free Encyclopedia, "Euthanasia." <http://en.wikipedia.org/wiki/ Euthanasia> (Accessed 22 August, 2008); see also The Encyclopedia Britannica, Online, "Thanatology.” <http://search.eb.com/eb/article9071928> (Accessed 22 August, 2008).

$2 \quad$ The quality of life principle has remained one of the strongest points of the advocates of euthanasia and assisted suicide. According to these category of persons, there is no need for a severely or terminally ill person to continue riding in pain, when there is no hope for his recovery, he should either kill him self or be assisted to do so. The conclusion of the advocates here is that, such patient's quality of life can never be the same again, i.e. he can no longer do what he had hitherto been doing while healthy. It is however important to mention here that statement of this kind, rather than the illness itself, have remained the cause for many request for euthanasia and assisted suicide as we have it today. This is so because, such persons, out of fear of abandonment and being a burden to families and friends would opt for euthanasia and or assisted suicide. See also n. 3 below; "Second Dublin Venue bows to Pressure and cancel Euthanasia Meeting." http:// www.peacefulpill.blogspot.com/2010/03/2nd-dublin-venue-bows-topressure-and-html> (Accessed 3 March, 2010). According to the world's acclaimed 'Dr Death,' Philip Nitschke, while describing the series of 
when a person is suffering from a protracted, severe or terminal illness and he is in pain, it will be better, according to the advocates of this principle, for such a person to take his or her own life. The premise of this argument, according to the advocates lies in the fact that once you are in pain due to a debilitating illness, you are no longer useful, it would then be better to die. ${ }^{3}$ However, opponents of this principle rely heavily on the sacredness of life to say that irrespective of the nature of the illness, a sufferer should never initiate the process of taking his own life, rather, proper care and treatment should be given to such a person until death comes naturally. ${ }^{4}$ The advocates of the sanctity of life principle

meetings and workshop he has held, wherein he teaches people how to commit suicide all over the world, he said that, "our meetings empower people with information to ensure that careful, informed decisions can be made when and if a time should come that one's quality of life is so poor that death is a preferable option." This statement without doubt attests to the fact that the quality of life principle is held in high esteem, such that when it (quality of life) is poor, in the estimation of the advocates, like Philip Nitschke above, euthanasia and assisted suicide is seen as the only option. The man is referred to as 'Dr Death,' because he became the first physician in the world to provide legal voluntary euthanasia to four patients, when the concept was legalized in Australia under the Australian Northern Territory Rights of the Terminally Ill (ROTI) Act, 1995. It is important to state that his act in killing the four, who were later discovered to be only at the early stage of the illness, led to the repeal of the law, within six months of its passage. See also Northern Territory Government (1995) Rights of the Terminally Ill Act, National Territory of Australia; Darwin: Government Publisher. $<$ http://www.lexisnexis.com/us/inacademic/result> (Accessed 6 August, 2008).

3 A British moralist says Dementia patients have a duty to die. < http:// aconstatineblacklist.blogspot.com/2008/09/useless-eaters-britishmoralist-says.html> (Accessed on 26 September, 2008). Baroness Mary Helen Warnock, like many advocates of the modern utilitarian principle, called those suffering from dementia, 'useless eaters.' She said they are wasting the scarce resources of the United Kingdom, and so suggested that they should consider taking their own lives or pay for their own treatment.

$4 \quad$ The Qur'an (Al- Maidah: 32). This principle, as opposed to quality of life, states that, a person has no right to take his own life, because he is not the creator of that life. The argument goes further to say that even debilitating illnesses should never be a basis for it. 
are mainly religious adherents. The reason is that only God can create life, so no human being should possess the right to take the life he does not contribute anything to its making. Thus, this article examines the arguments for and against the principle. It will also reflect on whether or not the principle has any place in Islamic law.

\section{DEFINITION}

As stated earlier, quality of life does not have any specific definition. ${ }^{5}$ According to the ecological economist, Robert Costanza, 6 " "while quality of life has long been an explicit or implicit policy goal, adequate definition and measurement have been elusive." 7 The elusive nature of the principle notwithstanding, quality of life is defined as, "anything which is used to evaluate wellbeing of individual and societies...” "include not only wealth and employment, but also the environment, physical and mental health, education, recreation and leisure time, and social belonging." ${ }^{9}$ According to the American Society for Gastrointestinal Endoscopy, quality of life means, "the perception of ability to meet daily needs." ${ }^{10}$ It has equally been defined from another perspective to mean:

$5 \quad<$ http://www.wikipedia.org/wiki/Quality_of_life> (Accessed on 21 March, 2010).

6 Robert Costanza, Brendan Fisher, Saleem Ali, Caroline Beer, Lynne Bond, Roelof Boumans, Nicholas L. Danigelis, Jennifer Dickinson, Carolyn Elliott, Joshua Farley, Diane Elliott Gayer, Linda MacDonald Glenn, Thomas R. Hudspeth, Dennis F. Mahoney, Laurence McCahill, Barbara McIntosh, Brian Reed, Abu Turab Rizvi, Donna M. Rizzo, Thomas Simpatico and Robert Snapp Costanza, (2008) "An Integrative Approach to Quality of Life Measurement, Research, and Policy." S.A.P.I.EN.S, vol. 1(1).

Ibid.

$8 \quad$ Supra n.4; see also. “Quality of Life.” Dictionary of Human Geography, 5th ed. Oxford: Wiley-Blackwell, (June 2009).

$9 \quad$ Ibid.

10 Gastrointestinal Glossary of Terms:<http://www.asge.org/ pressroomindex.aspx?id+560> (Accessed 21March, 2010); see also MedicineNet.com. 
"the overall enjoyment of life."11 Similarly, an on-line dictionary describes quality of life as, "one's personal satisfaction (or dissatisfaction) with the cultural or intellectual condition under which a person lives (as distinct from material comfort)." ${ }^{12}$ According to a medical dictionary, quality of life is very important when it comes to medical care. It therefore defines quality of life, as, "the patient's ability to enjoy normal life activities." ${ }^{13}$ In the same vein, another writer puts it this way, "the best way of approaching quality of life measurement is to measure the extent to which people's 'happiness requirements' are met - i.e. those requirements which are a necessary (although not sufficient) condition of anyone's happiness - those "without which no member of the human race can be happy." 14 In his own view, Frankli, is of the opinion that, "quality of life is tied to perception of 'meaning'. The quest for meaning is central to the human condition, and people are brought in touch with a sense of meaning when they reflect on that which they have created, loved, believed in or left as a legacy." 15 The Ontario Social Development Council describes quality of life, as, "the product of the interplay among social, health, economic and environmental conditions which affect human and social development." ${ }^{16}$ A much more encompassing definition is the one given by the research unit of the University of Ontario. ${ }^{17}$ According to the research unit, quality of life refers to the degree to which a person enjoys the important possibilities of his life. ${ }^{18}$ In its view, these possibilities which

11 Glossary of Cancer Terms:<http://www.mdanderson.org/patients-andcancer-information/cancer-information/glossary-of-cancer-terms/ q.html (Accessed on 21 March, 2010).

$12<$ http://www.thefreedictionary.com/quality+of + life $>$ (Accessed on 22 March, 2010).

13 Definition of Quality of Life.<http://www.medterms.com/script/main/ art.asp?articlekey=11815> (Accessed 22 March, 2010).

$14 \quad$ McCall, S. 1975, 'Quality of Life', Social Indicators Research 2, pp 229248; see also <http://www.gdrc.org/uem/qol-define.html> (Accessed 21 March, 2010).

$15 \quad$ Frankli, V. E. 1963. "Man’s search for meaning.” New York: Pocket Books, n.p; see also n. 13 above.

16 Ontario Social Development Council, 1997.

17 “Quality of Life: How good is Life for you?” University of Toronto Quality of Life Research Unit.<http://www.utoronto.ca/qol/> Retrieved October 14 2009. (Accessed 21 March, 2010). Ibid. 
is divided into three aspects, represent the outcome of the views of various writers on the subject matter.

Thus, in line with the above definition, the three main domains of life are 'being,' 'belonging,' and 'becoming.' These three are equally subdivided into three sub-areas. The three domains shall therefore be examined in turn. First and foremost, 'being' is also sub-divided into three, namely, physical appearance, psychological being and spiritual being. The totality of all the 'beings' refers to one's nutrition, health, feelings and spiritual beliefs. ${ }^{19}$ 'Belonging' on the other hand can also be seen under three sub-heads. These sub-heads include, physical belonging, social belonging, and community belonging. The summary of all the belongings relates to one's physical environment, work place, and home, relationship with one's immediate family, friends and the community at large. It also includes good health, access to education and good recreational facilities. ${ }^{20}$ 'Becoming' is also sub-divided into three, namely; practical becoming, volunteer becoming and leisure becoming. All the above subdivisions relates one's relationship with the achievement of set objectives in life, day to day activities, and the ability to leisure, like playing games and cards, being able to visit families and relations, and embarking on long vacations as a way of reducing stress or relaxing amongst others. ${ }^{21}$

A careful perusal of all the above definitions points to the same fact that quality of life simply refers to good health and well being, which would invariably lead to one's ability to do all that is required to be done in life. These include the ability to study, work, and play. It also involves visiting friends, and being accepted by such friends, families and wellwishers. It will therefore be reasonable to say that proponents of euthanasia and assisted suicide derive support from all of the above definitions, in order to push for the legalization of the concept. As far as the advocates of the quality of life principle are concerned, if a person is no longer healthy, or one's condition of health has deteriorated to the extent that such person can no longer do what he ought to do, when active, he should be allowed to die with dignity.

The above observation finds support in the operative words of the state of Oregon and Washington in the United States of America and

$\begin{array}{ll}19 & \text { Ibid. } \\ 20 & \text { Ibid. } \\ 21 & \text { Ibid. }\end{array}$


the Netherlands laws on euthanasia and assisted suicide. For instance, the Death with Dignity Act, 1997, being the law in the state of Oregon, which is also identical with that of Washington provides that a person shall be qualified to get prescription for suicide if his illness is such that he would not last beyond six months..$^{22}$ The Netherlands law on the other hand, provides that a person whose illness has become unbearable shall be qualified to either kill himself, or be assisted to die. ${ }^{23} \mathrm{~A}$ careful examination of these two laws would show that euthanasia and or assisted suicide is being provided as an option to a deteriorating state of health. In other words, euthanasia and assisted suicide is seen as an answer to poor quality of life.

\section{ARGUMENTS IN SUPPORT OF THE QUALITY OF LIFE PRINCIPLE}

Quality of life remains the major reason why the advocates of euthanasia and assisted suicide are pushing for the legalization of the concept. It is their view that terminally ill persons undergo severe pain, which ultimately affects the state of their health negatively. At this stage, they state that such life should be brought to an end. In other words such persons should, rather than continue to wallow in pain, be allowed either to take their own lives, or be assisted to do so. It is important to emphasise here that the quality of life principle is a creation of the modern school of utilitarianism. This is because its adherents believe strongly that lives that are unworthy should be replaced with worthy ones. ${ }^{24}$ The import of

$22 \quad$ Oregon’s Death with Dignity Act, 1997 (ORS 127. 800-8987) and Washington's Death with Dignity Act, 2008 (Initiative 1-1000). Both laws provide that incurably ill patients with less than six months to die are qualified for prescription so they could die with dignity. Wet toetsing levensbeeindinging op Verzoek en hulp bij zelfdodoing (Termination of Life on Request and Assisted Suicide (Review Procedure) [Act], Van 1 April, 2001, Staatsblad, 2001, 194. Under this law, the words unbearable, hopeless and lasting suffering qualify one for euthanasia and assisted suicide. These words are employed to show that the patient's quality of life has gone worse, and he should therefore be terminated. 
the above statement is that terminally ill, aged, disabled and other vulnerable people in our society should be eliminated under the guise of poor quality of life. Advocates of this principle hinged their support further on the fact that the taking of life is also humane, since the person dying is doing so with dignity. ${ }^{25}$ Thus, they are of the view that since death is inevitable, it will be humane to put an end to the life of a person undergoing serious pain as a result of an incurable illness. ${ }^{26}$ This is because, from their own point of view, it is only the person suffering that can ascertain or determine whether he or she is tired of living or not. ${ }^{27}$ Life to these categories of persons belongs to the owner, rather than Allah (God). Credence was given to this view recently by the world's renowned " $\mathrm{Dr}$ Death”, Philip Nitschke, while delivering a speech on euthanasia in Ireland. He said that, "as an atheist... I am constantly up against this idea that somehow life belongs to God. I disagree strongly with that assertion."28

\section{ARGUMENTS AGAINST THE PRINCIPLE OF QUALITY OF LIFE}

Arguments against the quality of life principle, as earlier stated, are largely based on religious ground. This is expected considering the fact that the popular religions in the world, Islam and Christianity place lots of emphasis on the sanctity of life as opposed to quality of life. Although, the Islamic stand point shall be fully discussed, it is important to refer to the reaction of Allah (s.w.t) when Qâbil (Cain) killed his brother Hâbil (Abel), both men were sons of Prophet Adam. On the basis of the killing, Allah (s.w.t)

\footnotetext{
231-265: 241. <http://www.pregnantpause.org/admin/contact.htm> (Accessed 17 July, 2008). Bach A, "Medico-Legal Congress” vol. 14 (1896) Medico-Legal Journal 103-106; see also Anthony, O.Nwafor,"Euthanasia-Religion, Medical Ethics \& Law," A journal of contemporary legal allied issues, vol. 1, No.2 (2004) Ife juris Review, 264-276.

26 Supra, Anthony Nwafor, n. 25.

$27 \quad$ Ibid.

28 "Plan Now for Suicide; Australia's Dr Death encourages Elderly Irish.” <http://www.lifesitenews.com/idn/2010/mar/10032302.html > (Accessed 19 March, 2010).
} 
outlawed, and regards as sin, the intentional killing of one another. In doing this, He regards the killer of one person as being the killer of a whole generation. However, Allah (s.w.t) states that it will be lawful to kill a person, who had earlier murdered another person. ${ }^{29}$ Similarly, a person can be killed by virtue of a sentence of a Shari'ah court decision, where such decision finds a married person guilty of adultery, or in a case of proven apostasy (a person who reverts from Islam and goes on blaspheming the religion). ${ }^{30}$

Christianity like Islam, abhors the killing of one another. It is clearly stated in the Holy Bible, that, "thou shall not kill." ${ }^{11}$ Thus, in line with this position, the Catholic community in Washington, while emphasizing the importance of life in their condemnation of euthanasia and assisted suicide, states that the concept will lead to, "a fundamental change in civil law that reduces the value of human life to its 'usefulness' in utilitarian terms." ${ }^{32}$ In the same vein, a woman, while stressing the importance attached to the value of life, said she opposed assisted suicide

Supra n. 4.

Al-Bukhari \& Muslim, Imam Al-Nawawi, collection of hadith, No. 14. $<$ http://fortyhadith.iiu.edu.my/hadith14.htm> (Accessed 16 September, 2009).

See the King James Version of the Holy Bible, Exodus 20:13-14; see also Chapter 20 of the Roman Catholic New American Bible; Deuteronomy 5:17. Like the Qur'an, the Bible also allows the killing of another person, when the former had earlier killed another, Exodus 21:12-14; Leviticus, 24:17 \& 21. Killing is also allowed in the Bible in some other situations like adultery, Leviticus, 20:10, Deuteronomy, 22:2224; Accidental killing or killing due to mistakes do not carry the death penalty, Numbers 35:9-34; Deuteronomy 19:1-3. All the above provisions attest to the fact that religion upholds the principle of sanctity of life as opposed to its quality.

When we say the value of human life is, as a consequence of allowing euthanasia and assisted suicide, reduced to its usefulness in utilitarian term, it means that the utilitarian principle is aimed at sacrificing the lives of the disabled and terminally ill persons, for the good of the society. This will then be in line with the proposition of the proponents of euthanasia, which is that, the aged, disabled and severely ill people are either unworthy of living or are useless eaters, and so should be killed. The essence is to give attention to those who, according to their judgement, are healthy. See also, supra n. 3. 
after the death of her husband, having realised that life is valuable to its very end..$^{33}$

In the view of another clergy, Father Pavone, a lack of respect for the sanctity and dignity of the human life of one person amounts to the destruction and violation of the sanctity and dignity of every other person. ${ }^{34} \mathrm{~A}$ member of the European Parliament, in joining forces with the opponents of quality of life said that, the killing of one another because of terminal illnesses amounts to selfishness. The parliamentarian stated further that when this happens, it means that the society no longer values life. ${ }^{35}$

\section{THE ISLAMIC LAW POSITION ON THE PRINCIPLE OF QUALITY OF LIFE}

As earlier stated, the importance attached to life is one of the main priorities of Islam. Thus, Islam is against the taking of life of one another, although there are instances where life can be taken. ${ }^{36}$ It is this importance that necessitated Allah's response to the killing of Hâbil (Abel) by his

33 The woman, Rheba, De Tornyah, is the Dean Emeritus of the University of Washington's School of Nursing., <http://www.noassistedsuicide. com/newsart26.html> (Accessed 29 September, 2008).

Terri Schiavo Remembered, <http//www.thenewamerican.com/culture/ family/952> (Accessed 2 April, 2009). Father Frank Pavone is the President of the priest for life. He made this statement during the fourth year remembrance church service in honour of Terri Schiavo, who was dehydrated to death on the orders of a Florida District Court in 2005. Nirj Deva, is the head of the Pro-Life Caucus at the European Union's Parliament. He expressed concern about the increasing demographic instability in the European Union (EU), which he said was the result of the approval of abortion, contraception, and euthanasia. He expressed this view at the blog for life conference held on January 22, 2009. $<$ http ://deaconJohn1987.liveJournal.com/437399.html> (Accessed 23 January, 2009).

36 See $n$. 38 below. According to the verse, the life of a Muslim cannot be taken by another Muslim, except under certain conditions. These conditions include unlawful killing, zina (illegal sexual intercourse) and apostasy. Hence the notion of killing a person because he is terminally ill or in pain has no support in Islam. 
brother Qâbil (Cain). Allah (s.w.t) says, “on that account, we ordained for the children of Israel that if any one slays a person - unless it be [is] for murder or spreading mischief in the land, it would be as if he slew the whole people. And if anyone saves a life, it would be as if he saved the life of the whole people." ${ }^{37}$ Allah (s.w.t) however says that a person may be killed for a just cause as where such person has committed adultery or has unlawfully killed another innocent person . In all these cases however, only a Shari'ah court of competent jurisdiction can order such killing. He re-emphasizes further that whosoever kills another, the families of the person killed have a right of retaliation in Islamic law. Thus, He says,

...And do not kill anyone whose killing Allah has forbidden, except for a just cause. And whoever is killed wrongfully (Mazlûman intentionally with hostility and oppression and not by mistake), We have given his heir the authority [to demand Qisas,- Law of Equality in punishment- or to forgive, or to take Diyah (blood money]. But let him not exceed limits in the matter of taking life (i.e. he should not kill except the killer). Verily, he is helped (by the Islamic law). ${ }^{38}$

In another verse, Allah (s.w.t) also shows that He alone created mankind and therefore reserves the right to take his soul whenever He wants. This was re-emphasized by Him in Surah al-Nahl, wherein Allah (s.w.t) says, “...And no person can ever die except by Allah's leave and at an appointed term...." ${ }^{39}$ Thus, from this verse, it can be understood that nobody has the right under Shari'ah to kill his fellow human being, except in permitted circumstances.

All the above verses point unequivocally to the fact that the quality of life principle does not exist in Islam, rather the law (Islamic Law), regards and hold in highest esteem the principle of the sanctity of life.

\footnotetext{
$37 \quad$ Supra n. 4.

38 The Qur’ân (al- Isrâ': 33).

39 The Qur’ân (al- Imrân: 145).
} 


\section{THE HADITH OF PROPHET MUHAMMAD (S.A.W)}

Sunnah or hadith refers to the words, deeds and actions of Prophet Muhammad (s.a.w). It is therefore meant to complement the Holy Qur'ân in situations where the Qur'ân is silent or brief on certain issues, to that extent it becomes one of the primary sources of Islamic law. An examination of some hadiths in support of the sanctity of life, as against its quality is relevant. For instance, Jundub, said, the Prophet (s.a.w) was reported to have said that, "a man sustained an injury during one of the wars in the early days of Islam, and he committed suicide, and so Allah said: My slave has caused death on himself hurriedly, so I forbid paradise for him." ${ }^{40}$ Similarly, Abû Hurairah was reported to have said that the Prophet (s.a.w.) said, "he who commits suicide by throttling shall keep on throttling himself in the Hell-fire and he who commits suicide by stabbing himself shall keep on stabbing himself in the Hell-fire." ${ }^{\prime 1}$ Furthermore, the Prophet (s.a.w) according to Abû Hurairah, was also reported to have said "avoid the seven great destructive sins. When asked by the people what those seven sins are? The Prophet (s.a.w) answered:

(1) to join partners in worship with Allah, (2) to practice sorcery; (3) to kill a person which Allah has forbidden except for a just cause (according to Islamic law); (4) to eat up Riba (usury); (5) to eat up the property of an orphan; (6) to show one's back to the enemy and fleeing from the battlefield at the time of fighting and (7) to accuse chaste women who never think of anything touching their chastity and are good believers. ${ }^{42}$

All the above attests to the fact that, except as stated above, a Muslim does not have the right to either take his own life, or be assisted to die. It follows therefore that terminal illness, debilitating disease, and excruciating pain, being the basis for relying on quality of life principle, as a means of killing oneself, has no place in Islam. It is also important to

\footnotetext{
$40 \quad$ (Sahih Al- Bukhârî, Vol. 2: 445).

41 (Al Bukhârî, Vol. 2: 446).

42 (Al Bukhârî, Vol. 8: 840).
} 
note here that all the schools of Islamic jurisprudence are in unanimity with the glorious Qur'ân and the Sunnah (hadith) of Holy Prophet Muhammad (s.a.w) regarding the sanctity of life, as against its quality. According to the four Sunni schools of law in Islam, intentional murder, if proven is a crime punishable with qisas. ${ }^{43}$ However, in placing reliance on the glorious Qur'an they are in unanimity that qisas (retaliation) or diyah (compensation) in lieu will apply. ${ }^{44}$ The above position is also shared by all contemporary scholars in Islam. ${ }^{45}$

$43 \quad$ Mohammed Shabbbir, Outlines of Criminal Law and Justice in Islam, International Law Books Series, Darul Ehsan, Selangor, Malaysia, 2002, 285 at 314.

A. Qoudah Shaeed, Criminal Law of Islam, trans. edn, S. Zakir Aijaz, Vol. 11, International Islamic Publishers, Delhi, India, 2001, at 146. The above is however dependent on the family of the deceased. In other words, if the victim's family is favourably disposed to avenging the death of their deceased relation, they would be right in doing so. This position is unanimous amongst all the classical school of Islamic jurisprudence. However, should they be interested in waiving their right of retaliation; they are equally allowed to accept compensation in lieu of retaliation. See also the Qur’ân (Qur’ân, al- Isra’: 33).

45 Yusuf al- Qardawi, Fatawa Mu'asirah, Dâr al-Wafa il al-Tiba’ah wa alNashr wa al-Tawzi, Egypt, 1993, vol. 2, at 527-529; see also Yusuf alQardawi, Questions \& Answer about Euthanasia in Islam, 2007. <http://www.islamonline:net/servlet/satellite?cid=1119503544774 \&pagename/islamonline-Ask_scholar/fatwa/fatwa E Ask The scholar> (Accessed 8 August, 2008); see also Aramesh \& Shadi, n. 82 at 36-37; Late Sheikh Abdul Aziz Abdullahi bin Bâz, 2007 <http:// www.islamicvoice.com/july.97/news.htm> (Accessed8 August, 2008); being part of the code of conduct drawn and called, "the Islamic Code of Medical Ethics," at the International Conference on Islamic Medicine held in Kuwait, 1981, at 67.It is important to note that Article 61 of the Code clearly abhors the quality of life principle as a reason to take one's life due to severe illness; Omar, H. K, "Euthanasia: Ethics- Legal Issues.” <http://www.Islamonline.net/english/news/2002-11/26/ article61.shtml> (Accessed 20 February, 2009); <http:// www.euthanasia.com/islamic.shtml.> (Accessed 13 March, 2009); Kiarash Aramesh \& Heyder Shadi, "Euthanasia: An Islamic Ethical Perspective” vol. 6, No. 5, 2007, Iranian Journal of Allergy, Asthma \& Immunology, pp. 35-38. 


\section{QUALITY OF LIFE, ILLNESSES AND ISLAMIC LAW}

It is important to re-state here that advocates of the quality of life principle are favourably disposed to the principle because to them, a terminally ill person should kill himself instead of wallowing in pain. With respect to these persons, Islamic law abhors the quality of life principle in all ramifications. This remains the case even in the face of a debilitating illness or excruciating pains. The wisdom of Islam here is that when a person is ill, it presupposes that he is undergoing a kind of reformation, and so should bear the suffering with patience. ${ }^{46}$ If he survives the ailment, the end result will be blessings for him. Where however, the illness takes away the life of such person, the person's sins will be forgiven by Allah (s.w.t). A person in Islamic law has no right to either take his own life or be assisted by any other person to do so. On this point, the Holy Qur'ân states that Prophet Luqman advised his son as follows:

My son! aqim al-salat [perform as-salat], enjoin [on people] al- ma' ruf-(Islamic Monotheism and all that is good), and forbid (people) from al-munkar [i.e. disbelief in the Oneness of Allah, polytheism of all kinds and all that is evil and bad], and bear with patience whatever befalls you. Verily, these are some of the important commandments [ordered by Allah with no exemption]. ${ }^{47}$

Lending support to the above verse, Anas, narrates that the Holy Prophet Muhammad, (s.a.w) was reported to have said, ${ }^{48}$

None of you should long for death because of a calamity that had befallen him; and if he cannot, but long for death, then he should say, O Allah! Let me live as long as life is better for me, and take my life if death is better for me. ${ }^{49}$

\footnotetext{
$46 \quad$ Sahih Muslim, Kitab-Al-Birr-Wa-Salat-l-Wal Adab, vol. 32: 6242. $<$ http://www.iiu.edu.my/deed/hadith/muslim032_smt.html> (Accessed 15 September, 2009).

47 Qur’ân, Luqman (31): 17); see also Qur’ân, az- Zuma (39): 10.

48 Sahih Al- Bukhari, Vol. 8: 362.

49 Ibid; see also The Qur’ân, Al-Hijr (15): 99.
} 
In another hadith, Abu Sa' id and Abu Hurairah, narrated that, the Prophet (s.a.w) said, "anytime a believer suffers hardship, calamity, grief or illness, his sins are forgiven by Allah." 50 Similarly, Jabir b. Abdullah narrated that the Prophet (s.a.w) visited one of the wives of his Sahabahs (disciples), Umm Musayyib, who was ill. ${ }^{51}$ It was stated that when the Prophet (s.a.w) sought to know why the woman was shivering, she said she was feeling feverish, she later cursed the illness. ${ }^{52}$ As a response to her act, Jabir said the Prophet (s.a.w) appealed to Umm Musayyib, never to curse illness, because fever atones for one's $\sin .{ }^{53}$

All the above hadiths are equally strengthened by the story of Prophet Ayyub (Job) which emphasises the irrelevance of the quality of life principle, as it discourages the taking of one's life because of sickness. ${ }^{54}$ Ayyub was reported to have suffered a chronic skin ailment, which lasted over 18 years, and yet he never gave up hope of recovery. He was steadfast in his worship of Almighty Allah (s.w.t), inspite of his condition, until he became well again..$^{55}$ Allah (s.w.t) responded to the faith Ayyub had in Him, by referring to him as an embodiment of patience. ${ }^{56}$ This scenario is a confirmation of Allah's resolve to reward patience. This is appropriately described by the Law Giver, Allah (s.w.t) Himself thus,

Say [O Muhammad]; O my slaves who believe [in the Oneness of Allah - Islamic monotheism], be afraid of your Lord [Allah] and keep your duty to Him. Good is [the reward] for those who do good [well] in this world, and Allah's earth is spacious [so if you cannot worship Allah at a place, then go to another]! Only those who

\footnotetext{
$50 \quad$ Ibid.

$51 \quad$ Ibid., 244.

52 Ibid.

$53 \quad$ Ibid.

$54 \quad$ Sayed Sikandar Sha (Haneef), "Mercy Killing in Islam: Ethical and Legal Issues,” [1996] 3 CLJ xciii; see also Icmad Al-din Isma‘il Ibn Kathir, "Qitab Al-Anbiyâ,” 1989, at 256-262; Mohammed Ibn Ahmed Al- Qurtubi, “Al-Jâmi Li Ahkâm Al-Qurân,” Vol. 7, nd, at 133.

55 Ibid.

56 The Qur'ân, Al-Anbiyâ: 83-84.
} 
are patient shall receive their reward in full, without reckoning. ${ }^{57}$

\section{CONCLUSION}

On the basis of all the above, it is submitted that the principle of quality of life does not exist in Islam. This is because Allah (s.w.t) places lots of importance on the sanctity of life, so that he who takes the life of another, unlawfully, except by mistake, risks capital punishment. It can therefore be safely concluded that there is no meeting point between the principle of quality of life and Islamic law, as the latter emphasizes sanctity of life as opposed to the former. This remains the case even in the face of severe illness, as Islam believes strongly that he, who is in pain either as a result of an illness or due to a calamity, will surely be forgiven his sins by Allah (s.w.t), if death eventually ensues. But where such person overcomes the ailment, he or she will become rejuvenated and strengthened in faith.

57 Qur’ân, az- Zuma (39): 10. 